\title{
“BUT I DIDN'T MEAN To": THE ROLE OF INTENT IN AMERICAN AND CANADIAN ANTI-PREFERENCE LAW
}

\author{
CLAYTON BANGSUND*
}

In both the United States and Canada, bankruptcy preferential transfer avoidance provisions are aimed at creating equality of distribution among similarly situated creditors. However, there is a key difference in the way each jurisdiction's regime treats the notion of intent. An analysis of each regime, using examples, illustrates the way in which Canada's regime effectually does violence to the distributive equality policy objective, while the US regime adheres to it.
Aux États-Unis comme au Canada, les dispositions de transfert préférentiel d'évitement de la faillite visent à créer une répartition égale parmi les créanciers semblables. Cependant, il y a une grande différence dans la manière dont chaque régime juridictionnel traite la notion d'intention. Une analyse de chaque régime illustre, au moyen d'exemples que le régime canadien fait violence à l'objectif de la politique de répartition égale, alors que le régime américain le respecte.

\section{TABLE OF CONTENTS}

I. InTRODUCTION $\ldots \ldots \ldots \ldots \ldots \ldots \ldots \ldots \ldots \ldots \ldots \ldots \ldots \ldots \ldots \ldots$

II. The American Preferential TRAnsfer Avoidance Regime . . . . . . 817
A. Historical EVOlution of AMERICAN PREFERENTIAL
TRANSFER AVOIDANCE PROVISIONS UNDER
BANKRUPTCY STATUTES .................... 817

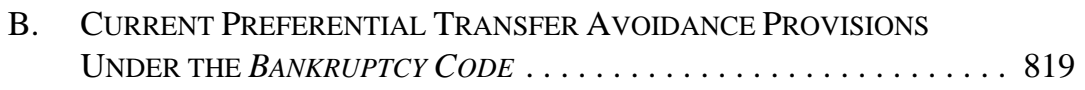

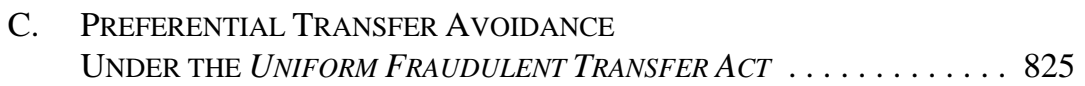
D. BRIEF SUMMARY OF THE AMERICAN PREFERENTIAL
Transfer Avoidance Provisions . . . . . . . . . . . . . 826

III. THE CANADIAN PREFERENTIAL TRANSFER

Avoidance Regime . . . . . . . . . . . . . . . . . . . . . . 827
A. RECENT AMENDMENTS TO THE CANADIAN BANKRUPTCY
Preferential Transfer Avoidance Provisions . . . . . . . . 827

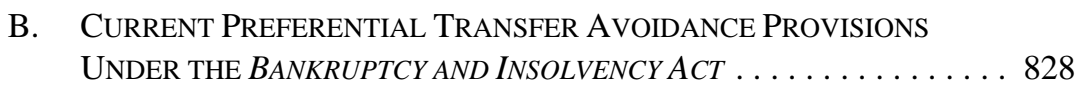

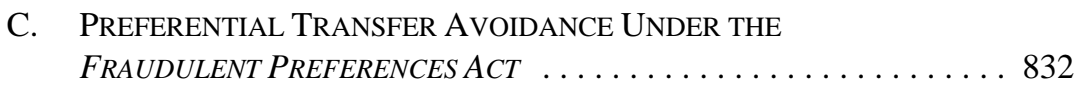
D. BRIEF Summary of THE CANAdian PREFERENTIAL
Transfer Avoidance Provisions . . . . . . . . . . . . . 835

IV. COMPARATIVE ANALYSIS OF AMERICAN AND CANADIAN

Preferential Transfer Avoidance Provisions $\ldots \ldots \ldots \ldots . . . .836$

BEd (University of Regina), JD (University of Alberta), LLM (Columbia University), Ph.D. candidate (University of Alberta); Assistant Professor (effective January 1, 2014), University of Saskatchewan, College of Law. I would like to thank Professors Ronald J Mann (Columbia University), Ronald CC Cuming (University of Saskatchewan), Tamara M Buckwold (University of Alberta), and Roderick J Wood (University of Alberta), and two anonymous experts, for their excellent feedback on this article. All opinions are my own, and I take full responsibility for any errors. 


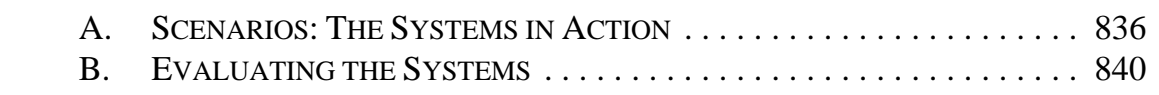

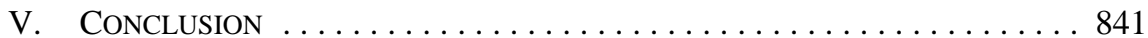

\section{Proverb "The road to hell is paved with good intentions."}

\section{INTRODUCTION}

Imagine the following scenario. In early January, Widgetco, a manufacturer of widgets, finds itself insolvent after a prolonged financial struggle through a deep recession. A number of suppliers, all unaffiliated with Widgetco, sell their goods and services to the company on credit. Widgetco has several delinquent accounts payable to each of the suppliers. Widgetco's president and chief executive officer realizes that, for the moment, the company cannot afford to pay each of the suppliers' outstanding accounts. She decides to pay the account of Supplyco, the most critical of Widgetco's suppliers, in the hope (and honest belief) that Widgetco can reverse its economic misfortunes and return to solvency and profitability. The remainder of the suppliers will go unpaid for the time being.

Despite Widgetco's best-laid plans, its financial situation continues to deteriorate, and in mid-February, Widgetco's board of directors decides that the company must make an assignment in bankruptcy, and directs the president and chief executive officer to immediately arrange such assignment. Charged with representing the interests of Widgetco's unsecured creditors, the trustee in bankruptcy impeaches the January payment to Supplyco, arguing that it is a voidable preferential transfer. Numerous factors will figure into the resolution of the matter, but will the outcome of the bankruptcy trustee's challenge depend on whether this series of events transpired in the United States or Canada? Maybe.

In both the $\mathrm{US}^{1}$ and Canada, ${ }^{2}$ provisions in the applicable federal bankruptcy and insolvency statutes give a trustee in bankruptcy the ability to impugn, and potentially avoid, certain preferential transfers made by the debtor on the eve of bankruptcy. ${ }^{3}$ In addition, various other state and provincial statutes give creditors the ability to challenge preferential transfers outside of bankruptcy, ${ }^{4}$ and further provide a trustee in bankruptcy with an alternate method of challenging preferential transfers within bankruptcy proceedings. The American and Canadian preferential transfer avoidance regimes are similar in many respects, but they also exhibit important differences. Focusing primarily on the bankruptcy and insolvency statutes, this article provides a comparative analysis of the regimes and investigates, in to US Const, art I, § 8, cl 4.

2 In Canada, Parliament has exclusive authority to make laws in relation to bankruptcy and insolvency pursuant to s 91(21) of the Constitution Act, 1867, (UK) 30 \& 31 Vict, c 3, reprinted in RSC 1985, App II, No 5.

3 In the US, the primary bankruptcy statute is the Bankruptcy Code, 11 USC. In Canada, the primary bankruptcy statute is the Bankruptcy and Insolvency Act, RSC 1985, c B-3 [BIA].

$4 \quad$ See e.g. Uniform Fraudulent Transfer Act, which is the US model legislation enacted in 43 states and the District of Columbia [UFTA] (Uniform Law Commission, Uniform Fraudulent Transfer Act (1984), online: <http://www.uniformlaws.org/Act.aspx?title=Fraudulent\%20Transfer\%20Act>); see also e.g. Fraudulent Preferences Act, RSA 2000, c F-24 (Alberta) [FPA]. 
particular, the extent to which intent plays a role in determining the outcome of antipreference challenges.

Part II of this article discusses section 547 of the Bankruptcy Code, ${ }^{5}$ including a brief description of the provision's historical evolution, its current status, the various defences available to creditors in receipt of impugned transfers, and the role of intent in determining whether a particular transfer is voidable under the statute. Part II also briefly discusses section 5(b) of the Uniform Fraudulent Transfer Act, ${ }^{6}$ model state legislation that gives (i) creditors the ability to challenge preferential transfers outside of bankruptcy, and (ii) the trustee in bankruptcy an alternate avenue of challenging preferential transfers within bankruptcy proceedings. Part III discusses section 95 of the Bankruptcy and Insolvency Act, ${ }^{7}$ Canada's functional equivalent of section 547. Part III also briefly describes sections 2 and 3 of Alberta's Fraudulent Preferences Act ${ }^{8}$ as an example of provincial statutory provisions that, similar to section 5(b) of the UFTA, give creditors the ability to impugn preferential transfers outside of bankruptcy. Part IV compares and contrasts the American and Canadian regimes with a specific focus on the role of intent, highlights the chief similarities and differences between the two, and, using as a benchmark the distributive equality policy objective, opines on which jurisdiction's regime reflects a more sensible approach with aspects that ought to be considered for adoption by the other. Part V sets out the conclusions.

\section{The American Preferential Transfer Avoidance Regime}

\section{A. Historical Evolution of American Preferential Transfer AVoidance Provisions Under BankRUPTCY STATUTES}

Since a principal focus of this article is the role of intent in determining whether a transfer made on the eve of bankruptcy ought to be avoided, it is instructive to review the role of intent in preferential transfer avoidance provisions that preceded section 547 of the Bankruptcy Code. Preferential transfer avoidance provisions have "been the subject of change in virtually every major effort undertaken to revise, update, or alter the substantive terms of bankruptcy powers, including the 2005 Amendments." "9 Anti-preference provisions are controversial because they are generally incompatible with state debt collection laws, and often contradict such laws entirely. Indeed, a validly effected transfer under state law may later become voidable if the debtor is petitioned into bankruptcy or voluntarily files for bankruptcy. ${ }^{10}$

Historically, a trustee in bankruptcy in the US was required to establish an element of "quasi-intent” in order to avoid a transfer made to a creditor on the eve of bankruptcy. ${ }^{11}$ The

Supra note 3.

Supra note 4.

Supra note 3.

Supra note 4.

William L Norton Jr, Norton Bankruptcy Law and Practice, 3d ed (St Paul: Thomson West, 2012) at § 66:1.

Ibid.

I use the term “quasi-intent” because neither the debtor nor the creditor need intend a preferential effect in order to satisfy the preferential transfer avoidance requirements. Rather, the creditor was simply required to have had "reason to believe the debtor was insolvent." However, the author goes on to describe how the Bankruptcy Act contains an intent element, stating the following: "However, the Code deletes this intent requirement, transforming the 90-day preference into a strict liability statute”: Norton, 
Bankruptcy Act ${ }^{12}$ provided that, among other things, the transfer be "made to a creditor who had reason to believe the debtor to be insolvent." ${ }^{33}$ Thus, under the Bankruptcy Act, the voidability of a transfer hinged, in part, on the mental state of the impugned creditor. This aspect of the rule came under great scrutiny because it only addressed one of the two policy objectives underlying preferential transfer avoidance. ${ }^{14}$ The first such policy objective is to deter creditors from aggressively pursuing a debtor on the brink of financial collapse. A "creditor race" is undesirable because it deprives the debtor of an opportunity to restructure its affairs for the benefit of all creditors, and further hastens its demise. The second policy objective, arguably more important than the first (and the more central focal point of this piece), ${ }^{15}$ is to create equality of distribution among similarly situated creditors. ${ }^{16}$ While the "reasonable cause" provision under the Bankruptcy Act may have deterred creditors from grabbing a distressed debtor's assets, it did not address the distributive equality policy objective. Thus, it was deemed deficient, and preferential transfer avoidance provisions were significantly revised in 1978 under the Bankruptcy Code to mandate, as a general rule, strict liability against a creditor receiving a payment or transfer from the bankrupt during the relevant look-back period. ${ }^{17}$ The Bankruptcy Code has been amended on various occasions since 1978, but its general approach respecting the impeachment of preferential transfers has remained relatively consistent.

ibid, § 66:19 [emphasis added].

Ch 541, 30 Stat 544 (1898).

Ibid at $\S 60 \mathrm{a}$.

Norton, supra note 9 at $\S 66: 4$, quoting the House Committee Report: “To argue that a creditor's state of mind is an important element ... is to ignore the strong bankruptcy policy of equality among creditors.” The House Committee was also of the view that the costs associated with litigating "state of mind" were excessive considering that such litigation did nothing to promote equality of distribution among creditors.

15 See Lawrence Ponoroff, "Evil Intentions and an Irresolute Endorsement for Scientific Rationalism: Bankruptcy Preferences One More Time” (1993) Wis L Rev 1439 at 1488, where the author suggests that the distributive equality principle is of greater importance than the "lesser" policy objective of deterring creditor races; see also Robert Weisberg, "Commercial Morality, the Merchant Character, and the History of the Voidable Preference” (1986) 39 Stan L Rev 3 at 119, where the principle of distributive equality is described as the "cornerstone" of the 1978 amendments to the Bankruptcy Code's preference provisions.

16 See Jay Lawrence Westbrook, “Choice of Avoidance Law in Global Insolvencies” (1991) 17 Brook J Int'l L 499 at 500 [footnotes omitted], where the author takes issue with the traditional enunciation of the second policy objective:

[O]ne element in the analysis is the rejection of the traditional incantation that all national avoidance laws have in common the goal of equality of distribution. In fact, inequality of distribution is the rule in virtually every national bankruptcy system. Therefore, the correct statement is that avoidance laws have as their function the protection and vindication of the priorities set by each national distribution scheme. That is, avoidance laws have as their central purpose overriding the results of individual creditor self-help in favour of politically determined community priorities.

Professor Westbrook's clarification point is well taken, but does not affect the views expressed in this article respecting the role of intent in determining the outcome of anti-preference challenges.

17 Alan N Resnick \& Henry J Sommer, eds, Collier on Bankruptcy, 16th ed (Davers, MA: Matthew Bender, 2012) at § 547.LH [Collier]. 


\title{
B. Current Preferential Transfer Avoidance Provisions UNDER THE BANKRUPTCY CODE
}

\section{SECTION 547(B) OF THE BANKRUPTCY CODE}

As noted above in Part A, the Bankruptcy Code's preferential transfer avoidance provision is aimed at promoting two policy goals. ${ }^{18}$ Elizabeth Warren and Jay Lawrence Westbrook eloquently describe the general nature of section 547 as follows:

\begin{abstract}
The Code makes it clear in section 547(b) that debtors cannot prefer certain creditors on the eve of bankruptcy and that creditors who seek such preferences will find them undone in bankruptcy. This has the effect of not only treating all like-situated creditors alike - "equity is equality" - but it also has a salutary effect on the debtor's business. For the debtor skirting the edges of financial demise, the voidable preference provisions create some disincentive for a creditor to expend time and money to extract preferential payments or security interests that will simply be avoided if the business cannot survive outside bankruptcy. The voidable preference section works to keep creditors from dismantling the ailing business, a deterrent that redounds to the benefit of all weak businesses as they deal with current creditors, whether or not the businesses ultimately enter bankruptcy. ${ }^{19}$
\end{abstract}

It is worthwhile examining precisely how the current version of section 547(b) achieves its aims. The provision is reproduced below:

Except as provided in subsections (c) and (i) of this section, the trustee may avoid any transfer of an interest of the debtor in property -

(1) to or for the benefit of a creditor;

(2) for or on account of an antecedent debt owed by the debtor before such transfer was made;

(3) made while the debtor was insolvent;

(4) made -

(A) on or within 90 days before the date of the filing of the petition; or

(B) between ninety days and one year before the date of the filing of the petition, if such creditor at the time of such transfer was an insider; and

(5) that enables such creditor to receive more than such creditor would receive if -

(A) the case were a case under chapter 7 of this title;

The objectives associated with anti-preference provisions are inextricably linked to, and subsumed within, the broader objectives of bankruptcy and insolvency law. See United Nations Commission on International Trade Law (UNCITRAL), Legislative Guide on Insolvency Law (New York: United Nations, 2005) at 9-14, where eight key objectives of an effective insolvency regime are identified by UNCITRAL: (1) Provide certainty in the market to promote economic stability and growth; (2) Maximize value of assets; (3) Strike a balance between liquidation and reorganization; (4) Ensure equitable treatment of similarly situated creditors; (5) Provide for timely, efficient, and impartial resolution of insolvency; (6) Preserve the insolvency estate to allow equitable distribution to creditors; (7) Ensure a transparent and predictable insolvency law that contains incentives for gathering and dispensing information; and (8) Recognize existing creditors rights and establish clear rules for ranking of priority claims. Note that the fourth general objective of insolvency law precisely mirrors the second anti-preference policy objective. This important policy objective (i.e. equal treatment of similarly situated creditors) informs the normative position set out in Part IV of this article.

19 Elizabeth Warren \& Jay Lawrence Westbrook, The Law of Debtors and Creditors: Text, Cases, and Problems, 6th ed (New York: Aspen Publishers, 2009) at 492. For another similar statement respecting the dual goals of § 547(b) of the Bankruptcy Code, see In re Ogden 314 F (3d) 1190 (10th Cir 2002) at 1196. 
(B) the transfer had not been made; and

(C) such creditor received payment of such debt to the extent provided by the provisions of this title.

Each of the five constituent elements of a voidable preferential transfer is worthy of explication. First, a "transfer" may take the form of, among other things, a payment of money or the granting of a security interest in respect of an antecedent debt. ${ }^{20}$ Second, in examining paragraphs (1) and (2) together, it is clear that there must have been a pre-existing debtorcreditor relationship to which the transfer relates. ${ }^{21}$

The third element of a voidable preferential transfer is that the debtor must be insolvent at the time the transfer is made. The term "insolvent" is not specifically defined for the purposes of section 547(b), so the general definition of the term, set forth in section 101(32) of the Bankruptcy Code, applies. Section 101(32) provides a "balance sheet" test of insolvency in which the aggregate of the debtor's debts must be greater than its assets at a fair valuation. This "balance sheet" test is to be contrasted with a "cash flow" test that focuses on whether the debtor has the ability to pay its debts as they become due. The Bankruptcy Code creates a presumption of debtor insolvency during the 90 days immediately preceding the bankruptcy. ${ }^{22}$ In order to rebut the presumption of insolvency, a creditor must introduce "some evidence" of solvency at the time of the transfer. ${ }^{23}$ If such evidence is introduced, the trustee in bankruptcy then bears the onus of establishing "proof of insolvency by a preponderance of the evidence."24

The fourth element of a preferential transfer is concerned with whether the transfer took place within the prescribed look-back period (sometimes called the "preference period"). The general look-back period is 90 days before the date of bankruptcy. ${ }^{25}$ A lengthier one-year look-back period applies if the creditor is an "insider" at the time of the transfer. ${ }^{26}$ The term "insider" includes a relative of the debtor if the debtor is an individual. ${ }^{27}$ If the debtor is a corporation, the term "insider" includes, among others, a director, officer, person in control, partnership in which the debtor is a general partner, general partner of the debtor, or relative of any of the aforementioned persons. ${ }^{28}$

In re Melon Produce, Inc, 976 F (2d) 71 (1st Cir 1992). It is also instructive to consider the broad definition of the term "transfer" set out in the Bankruptcy Code, supra note 3 at §101(54):

The term 'transfer' means -

(A) the creation of a lien;

(B) the retention of title as a security interest;

(C) the foreclosure of a debtor's equity of redemption; or

(D) each mode, direct or indirect, absolute or conditional, voluntary or involuntary, of disposing of or parting with -

(i) property; or

(ii) an interest in property.

In re Consolidated Industries Corp 292 BR 354 (ND Ind 2002) at 363: “An antecedent debt exists whenever the creditor has a claim against the debtor, even if the claim is contingent, unliquidated, or unfixed.” See also Freeland v Enodis Corp, 530 F (3d) 721 (7th Cir 2008).

Bankruptcy Code, supra note 3 at $\S 547(\mathrm{f})$.

In re Roblin Industries, Inc, 78 F(3d) 30 (2nd Cir 1996) at 34.

Ibid.

Bankruptcy Code, supra note 3 at $\S 547(b)(4)(A)$.

Ibid at $\S 547(\mathrm{~b})(4)(\mathrm{B})$.

Ibid at $\S 101(31)(\mathrm{A})$.

Ibid at $\S 101(31)(\mathrm{B})$. 
The fifth and final element that the trustee in bankruptcy must establish in order to avoid a preferential transfer is that the creditor would receive more by virtue of the transfer (combined with any distribution it might also be entitled to in the bankruptcy proceedings) than it would receive solely under a hypothetical Chapter 7 liquidation (that is, that there was a preferential effect). ${ }^{29}$ If the creditor is no better off for having received the transfer, the trustee will be unable to avoid the transaction.

\section{The Role OF INTENT UNDER SECTION 547(B)}

On its face, section 547(b) appears to treat intent (of both the debtor and creditor) as irrelevant in determining whether a transfer is voidable. In this regard, the provision is distinct from its predecessor provision under the Bankruptcy Act, which required the transferee to have had reason to believe that the debtor was insolvent. Indeed, pursuant to section 547(b) of the Bankruptcy Code, intent to prefer is largely irrelevant to the analysis when the transfer, in effect, affords a preference to the creditor. ${ }^{30}$ However, courts have recognized that intent may play a limited role under section 547. For example, in In re Perma Pacific Properties, ${ }^{31}$ the Court held that while "intent or state of mind of the parties is not materially dispositive of whether or not a transfer is a preference," the court may consider whether the parties intended to create the type of result that section 547 is meant to prevent. ${ }^{32}$

If one looked no further, they might conclude that intent plays no discernable role in determining whether a transfer is voidable under section 547 of the Bankruptcy Code. However, upon further examination of the provision, one discovers that intent is or may be a factor in determining whether a defence to a prima facie voidable transfer is available to the creditor. Section 547(c) of the Bankruptcy Code sets out nine defences ${ }^{33}$ that a creditor may rely on to "legitimize" an otherwise voidable transfer under section 547(b). Intent figures into the analysis in determining whether three of these defences are available.

\section{EXAMINING THE DEFENCES UNDER SECTION 547(C)}

Section 547(c) sets out nine defences that may be available to a creditor who received an otherwise voidable transfer. Several of the most common exceptions have their own jargon. ${ }^{34}$ Each of the defences is briefly described below:

(1) The "contemporaneous exchange" defence under section 547(c)(1). A creditor can avail itself of this defence if there is a minor delay between the time the creditor and debtor exchanged value.

(2) The "ordinary course payments" defence under section 547(c)(2). A creditor can avail itself of this defence if the transaction it effected with the debtor is not unusual and did not exhibit any intent to prefer.

In re PYSZ, 2008 WL 2001753 (Bankr DNH 2008).

In re Ogden, supra note 19 at 1201.

983 F (2d) 964 (10th Cir 1992).

Ibid at 968 . This statement is arguably erroneous given the plain wording of the provision.

The defences are also commonly referred to as “exceptions.” For the sake of simplicity, they are simply referred to as defences in this article.

Warren \& Westbrook, supra note 19 at 492. 
(3) The "purchase money security interest" defence under section 547(c)(3). A creditor may rely on this defence if, during the look-back period, it obtained a purchase money security interest in property acquired by the debtor with new value advanced by the creditor, provided that the creditor perfected its security interest within 30 days of the debtor receiving possession of such property.

(4) The "new value" defence under section 547(c)(4). A creditor can avail itself of this defence and diminish the amount of the trustee's avoidance to the extent it can establish that it advanced new value to or for the benefit of the debtor after an otherwise preferential transfer was made. ${ }^{35}$

(5) The "floating lien" defence under section 547(c)(5). This defence essentially allows a creditor a limited right to retain a security interest in inventory and accounts receivable (which by their very nature, are in a constant state of flux) that came into existence during the applicable look-back period. ${ }^{36}$

(6) The "statutory lien" defence under section 547(c)(6). This defence permits a transfer that takes the form of a statutory lien that violates section 547(b) if it is otherwise unavoidable under section 545. As explained by Elizabeth Warren and Jay Westbrook, this defence "means that statutory liens will be dealt with in section 545, notwithstanding their implications in section 547(b)."

(7) The "bona fide domestic support obligation" defence under section 547(c)(7). This defence is available to individuals who are entitled to alimony or support from the debtor. To the extent such an individual received a bona fide alimony or support payment from the debtor during the applicable look-back period, he or she is entitled to retain such payment notwithstanding that it would otherwise be voidable under section 547(b).

(8) The "consumer small transfer" defence under section 547(c)(8). This defence is only available when the debtor is an individual whose debts are primarily consumer debts. In such an instance, a creditor may retain the impugned transfer if the aggregate value of the property comprising the transfer is less than $\$ 600$, whether or not the particular transfer is in relation to a consumer debt or a business debt. ${ }^{38}$

(9) The "business small transfer" defence under section 547(c)(9). This defence is the functional equivalent of the "consumer small transfer" defence for a debtor (individual or otherwise) whose debts are not primarily consumer debts (that is, a business debtor). In this instance, a creditor may retain a transfer from the business 
debtor if the aggregate value of the property comprising the transfer is less than $\$ 5,000$. $^{39}$

Of the nine defences set forth in section 547(c), three are worthy of further examination due to the role intent plays in their respective analyses. These are the "contemporaneous exchange" defence, the "ordinary course payments" defence, and the "bona fide domestic support obligation” defence.

\section{a. The "Contemporaneous Exchange” Defence}

Under the "contemporaneous exchange” defence, a creditor can prevent the avoidance of an otherwise preferential transfer where the creditor and debtor intended to exchange value contemporaneously. A transaction in which a debtor's counterparty is the first to furnish value to the debtor necessarily gives rise to a period during which a debtor-creditor relationship exists. Technically, the debtor's subsequent transfer of value, though perhaps effectuated only moments after it received value from the "creditor," could be voidable under a section 547(b) preferential transfer analysis. The "contemporaneous exchange" defence saves the ostensible "creditor" from this cruel fate in carefully defined circumstances.

If the court concludes that the parties intended to make a contemporaneous exchange imagine two children trading baseball cards, and agreeing that each will release their card at the same time - and a "substantially contemporaneous exchange" occurred in fact (that is, the children actually release their respective trading cards within a short time interval), the challenged creditor is entitled to retain the transfer made by the debtor during the look-back period. ${ }^{40}$ The "substantially contemporaneous exchange" may occur over the course of months, depending on the unique circumstances of the case (such as, " length of delay, reason for delay, nature of transaction, intention of parties, possible risk of fraud"). ${ }^{41}$ In this sense, the "contemporaneous exchange" defence offers a measure of flexibility to the creditor asserting it. ${ }^{42}$ On the other hand, the rule is inflexible in that it is insufficient that a substantially contemporaneous exchange actually occurred if the parties did not specifically intend a contemporaneous exchange. ${ }^{43}$

The small transfer defences are more the result of lobbying efforts by creditors, than of any particular reasoned policy. See Warren \& Westbrook, supra note 19 at 507, where the authors state: "The justification is not principled so much as a claim by the creditors that they can't afford to litigate"; see also Charles J Tabb, “The Brave New World of Bankruptcy Preferences” (2005) 13 Am Bankr Inst L Rev 425.

$40 \quad$ Bankruptcy Code, supra note 3 at $\S 547$ (c)(1)(A) and (B).

41 In re McLaughlin, 183 BR 171 (Bankr WD Wis 1995) at 175; Pine Tops Ins Co v Bank of America Nat Trust \& Sav Ass'n, 969 F (2d) 321 (7th Cir 1992) at 328 [Pine Tops].

42 Norton, supra note 9 at $\S$ 66:35; See e.g. Pine Tops, ibid, where the Court held that a several week delay in effecting the transfer did not defeat the substantial contemporaneous nature of the exchange.

43 Norton, ibid. See In re Gateway Pacific Corp 153 F (3d) 915 (8th Cir 1998), where the president's lack of knowledge regarding a contemporaneous exchange showed the absence of any intent on the parties' part to create a contemporaneous exchange. 
b. The “Ordinary Course Payments” Defence

The purpose of the "ordinary course payments" defence is to "leave undisturbed normal financial relations" between the debtor and its creditors. ${ }^{44}$ The underlying notion is that permitting the debtor to make ordinary course payments during the look-back period does not detract "from the general policy of the preference section to discourage unusual action by either the debtor or his creditors during the debtor's slide into bankruptcy." 45 The first stage of the analysis requires a subjective determination that the debt, to which the transfer relates, was incurred in the ordinary course of business or financial affairs of the debtor and transferee. The second stage of the analysis involves (1) a subjective evaluation of whether the transfer was made in the ordinary course of business or financial affairs of the debtor and transferee (that is, whether the transfer was normal as between the parties), ${ }^{46}$ or (2) an objective evaluation of whether the transfer was made according to ordinary business terms. ${ }^{47}$ This latter objective element requires the creditor to introduce evidence that the transfer in question was common to the particular industry or generally accepted business practices. ${ }^{48}$

As noted above in Part A, a previous version of the preferential transfer avoidance provision required the creditor to have had "reason to believe the debtor was insolvent." The elimination of this intent element under section 547(b) of the Bankruptcy Code essentially created a strict liability rule. The "ordinary course payments" defence softens the harshness of the strict liability rule by permitting "normal" transactions that do not exhibit any preferential intent. ${ }^{49}$ Of course, the defence necessarily detracts, to a certain extent, from the policy goal of creating equality of distribution among unsecured creditors.

\section{c. The "Bona Fide Domestic Support Obligation” Defence}

There is remarkably little jurisprudence (case law or commentary) that elaborates on this defence. However, the term "bona fide" clearly connotes a mental element. Black's Law Dictionary ${ }^{50}$ defines the term "bona fide" as follows: "1. Made in good faith; without fraud or deceit. 2. Sincere; genuine.” It would therefore appear that in order for the defence to apply, a domestic support creditor who received a transfer (that is, a support payment) during the look-back period must simply demonstrate that the transfer was genuine and not a collaborative ruse between the debtor and creditor to swindle the debtor's general creditors.

\section{The ROLE OF INTENT UNDER SECTION 547(C)}

Although intent plays no discernible role in determining whether a transfer is prima facie voidable under section 547(b), it is relevant in determining whether three of the preferential transfer avoidance defences are available. In the “contemporaneous exchange” defence

In re Hedged-Investments Associates, Inc, 48 F (3d) 470 (10th Cir 1995) at 475.

Ibid.

In re Fulghum Const Corp, 872 F (2d) 739 (6th Cir 1989) at 743.

Tabb, supra note 39 at 440-41, where the author discusses the 2005 amendments to $\S 547(\mathrm{c})(2)$, which transformed a previously conjunctive rule into a disjunctive rule, thereby lessening the onus on a challenged creditor seeking to rely on the "ordinary course payments" defence.

Norton, supra note 9 at § 66:19. See In re Fred Hawes Organization, Inc, 957 F (2d) 239 (6th Cir 1992) at 244.

Tabb, supra note 39 at 440 .

9th ed (St Paul: West Publishing, 2009). 
context, the court is concerned with whether the debtor and creditor intended a contemporaneous exchange. In the "ordinary course payments" defence context, the court is concerned with whether the transfer made by the debtor during the look-back period is in any way "unusual" and thus reflects intention to prefer the challenged creditor. In other words, the court is interested in satisfying itself that there was an absence of preferential intent. Similarly, in the "bona fide domestic support obligation" context, the court is concerned with whether there was an absence of malicious intent.

\section{Summarizing THE ROLE OF INTENT UNDER SECTION 547}

In summary, section 547 of the Bankruptcy Code does not utilize intent as a primary ingredient in establishing a voidable preferential transfer. Rather, as a general matter, intent (or a demonstrated absence thereof) is viewed as a mitigating factor that, in certain circumstances, will permit a creditor to retain an otherwise voidable transfer.

\section{Preferential Transfer AVOIDANCE Under THE UNIFORM FRAUDULENT TRANSFER ACT}

\section{SECTION 5(B) OF THE UNIFORM FRAUDULENT TRANSFER ACT}

The UFTA is model legislation, introduced in 1984, that has been adopted in 43 states and the District of Columbia. ${ }^{51}$ Among its provisions is section 5(b), which creates a preferential transfer avoidance rule that is available to creditors of insolvent debtors who are not yet mired in bankruptcy proceedings. The provision is reproduced below:

\footnotetext{
A transfer made by a debtor is fraudulent as to a creditor whose claim arose before the transfer was made if the transfer was made to an insider for an antecedent debt, the debtor was insolvent at that time, and the insider had reasonable cause to believe that the debtor was insolvent.
}

One of the most striking features of section 5(b) is that, unlike section 547(b) of the Bankruptcy Code, it labels a violating transfer as "fraudulent," thereby imputing an immoral character on the transfer. Notably, section 5(b) of the UFTA applies only to transfers made to "insiders," 52 and therefore cuts a narrower swath than section 547 of the Bankruptcy Code. Reminiscent of section 60a of the Bankruptcy Act (the predecessor to section 547 of the Bankruptcy Code), section 5(b)(2) requires the insider to have "had reasonable cause to believe that the debtor was insolvent." Thus, the mental state of the insider, measured objectively, is an element that must be proven by a challenging creditor. This requirement is consonant with section 5(b)'s use of the term "fraudulent."

Similar to the relief granted under the Bankruptcy Code, the UFTA provides for avoidance of a preferential transfer under section $5(\mathrm{~b}) .{ }^{53}$ Section 9 (c) of the UFTA provides a time limit barring a creditor from bringing a claim under section 5(b) after one year from the date of the impugned transfer. This "statute bar” differs from the look-back period prescribed under definition of the same term in § 101(31) of the Bankruptcy Code, supra note 3.

UFTA, supra note 4 at $\S 7(a)(1)$. 
section 547(b)(4) of the Bankruptcy Code, which is solely concerned with whether the impugned transfer took place within a prescribed timeframe immediately preceding the debtor's bankruptcy (which, obviously, is irrelevant under a UFTA analysis).

Section 8(f) of the UFTA provides insiders with three defences. First, "to the extent the insider gave new value to or for the benefit of the debtor after the transfer was made," the insider may retain the transfer. ${ }^{54}$ This defence is reminiscent of the "new value" defence under section 547(c)(4) of the Bankruptcy Code. Second, a transfer to an insider by an insolvent debtor is not voidable "if made in the ordinary course of business or financial affairs of the debtor and the insider." 55 This defence is the functional equivalent of the “ordinary course payments” defence prescribed under section 547(c)(2) of the Bankruptcy Code. Finally, a transfer to an insider by an insolvent debtor is not voidable "if made pursuant to a good-faith effort to rehabilitate the debtor and the transfer secured present value given for that purpose as well as an antecedent debt of the debtor." 56 This defence is unique in that it does not neatly parallel any of the defences set out in section 547(c). Interestingly, however, the absence of fraud or deceit (that is, good faith) is a key component of the defence.

\section{Availability OF SECTION 5(B) TO THE TRUSTEE IN BANKRUPTCY VIA SECTION 544(B)(1) OF THE BANKRUPTCY CODE}

Section 544(b)(1) of the Bankruptcy Code provides the trustee in bankruptcy with, among other things, the avoidance powers of a creditor under section 5(b) of the UFTA. The power granted to the trustee in bankruptcy under section 544(b)(1) is in addition to (and not in substitution for) the trustee's avoidance power under section 547(b).$^{57}$ Therefore, in states that have adopted the UFTA, a trustee in bankruptcy may elect to pursue a preferential transfer under section 547 of the Bankruptcy Code, or under section 544(b)(1) of the Bankruptcy Code in conjunction with section 5(b) of the UFTA.

\section{Brief Summary Of THE AMERICAN PREFERENTIAL Transfer AVoidance Provisions}

Under section 547(b) of the Bankruptcy Code, both insiders and non-insiders are subject to a prima facie preferential transfer avoidance rule that focuses on the effect of the transfer. The chief difference in the treatment of insiders and non-insiders is the length of the applicable look-back period for each (that is, one year for insiders, and 90 days for noninsiders). Both insiders and non-insiders are able to avail themselves of the narrowly defined defences available under section 547(c), only three of which place any emphasis on the parties' intent (that is, the "contemporaneous exchange" defence, the "ordinary course payments" defence, and the "bona fide domestic support obligation” defence). Thus, a 
recipient of a transfer made within the look-back period may, in certain instances, hold intent up as a "shield" to a trustee's challenge. ${ }^{58}$

Outside of bankruptcy, the UFTA allows a creditor to challenge a preferential transfer made by an insolvent debtor to an insider. The challenging creditor must demonstrate that the insider had reason to believe that the debtor was insolvent. The insider may avail itself of three defences, two of which place some emphasis on the parties' intent: the "ordinary course" defence and the "bona fide debtor rehabilitation" defence. In bankruptcy, a trustee in bankruptcy may impeach a transfer using the UFTA in conjunction with section 544(b)(1) of the Bankruptcy Code.

\section{The Canadian Preferential Transfer Avoidance Regime}

\section{A. RECENT AMENDMENTS TO THE CANAdian BANKRUPTCY Preferential Transfer Avoidance Provisions}

Section 95 of the BIA, the functional equivalent of section 547(b) of the Bankruptcy Code, was amended in 2007. ${ }^{59}$ The pre-2007 version of section 95 (in conjunction with then section 96) generally provided that a transfer made by an insolvent person, within the applicable preference period, with a view to prefer a transferee, was “deemed fraudulent and void as against ... the trustee in the bankruptcy." 60 Thus the provision contained an intent element and imputed voidable transfers with an immoral character. Furthermore, the general preference period was three months before the date of the initial bankruptcy event. However, the preference period was extended to one year before the date of the initial bankruptcy event if the transferee was "related" to the debtor.

The 2007 amendment to section 95 of the BIA, the details of which are explored in greater detail below, effected three chief variations to the provision. First, it replaced the "related person versus unrelated person” dichotomy with an "arm's length versus non-arm's length" dichotomy. Second, it abandoned statutory language characterizing the voidable transaction as fraudulent, deemed or otherwise. Third, it created a "strict liability" anti-preference rule for non-arm's length transferees receiving transfers during the look-back period by eliminating intent to prefer as a necessary element. Despite the 2007 amendment, the preamendment version of section 95 is substantially similar to the post-amendment version, especially in respect of its treatment of arm's length creditors.

\footnotetext{
$58 \quad$ See Ponoroff, supra note 15 at 1481, where the author describes the $\S 547$ framework as providing a "'backdoor' way of reintroducing a moral standard into preference law."

59 Budget Implementation Act, 2007, SC 2007, c 29, s 100; An Act to amend the Bankruptcy and Insolvency Act, the Companies' Creditors Arrangement Act, the Wage Earner Protection Program Act and chapter 47 of the Statutes of Canada, 2005, SC 2007, c 36, s 42 [2007 Amendment Act]. 


\section{B. Current Preferential Transfer Avoidance Provisions UNDER THE BANKRUPTCY AND INSOLVENCY ACT}

\section{SECTION 95 OF THE BANKRUPTCY AND INSOLVENCY ACT}

The amended version of section 95(1) of the BIA is reproduced below:

A transfer of property made, a provision of services made, a charge on property made, a payment made, an obligation incurred or a judicial proceeding taken or suffered by an insolvent person

(a) in favour of a creditor who is dealing at arm's length with the insolvent person, or a person in trust for that creditor, with a view to giving that creditor a preference over another creditor is void as against — or, in Quebec, may not be set up against — the trustee if it is made, incurred, taken or suffered, as the case may be, during the period beginning on the day that is three months before the date of the initial bankruptcy event and ending on the date of the bankruptcy; and

(b) in favour of a creditor who is not dealing at arm's length with the insolvent person, or a person in trust for that creditor, that has the effect of giving that creditor a preference over another creditor is void as against — or, in Quebec, may not be set up against — the trustee if it is made, incurred, taken or suffered, as the case may be, during the period beginning on the day that is 12 months before the date of the initial bankruptcy event and ending on the date of the bankruptcy.

Unlike section 547(b) of the Bankruptcy Code, section 95(1) is not set out in paragraphs that neatly delineate the provision's component parts. Accordingly, it is helpful to take the additional step of dividing the provision into its constituent elements. In order to avoid a transfer, the trustee in bankruptcy must establish the following under section 95(1):

(1) That the debtor transferred property, provided services, charged property, made payment, incurred an obligation or suffered judicial proceedings (collectively referred to in this Part III as the "transfer”);

(2) That the debtor was insolvent at the time of the transfer;

(3) That the transfer was in favour of the creditor;

(4) (a) If the creditor is dealing at arm's length with the debtor, that the transfer occurred between the date that is three months immediately preceding the date of the initial bankruptcy event and the date of the bankruptcy; or

(b) If the creditor is not dealing at arm's length with the debtor, that the transfer occurred between the date that is twelve months immediately preceding the date of the initial bankruptcy event and the date of the bankruptcy; and 
(5) (a) If the creditor is dealing at arm's length with the debtor, that (i) the transfer had the actual effect of giving the creditor a preference over the debtor's other creditors, and (ii) the debtor intended to give the creditor such preference; or

(b) If the creditor is not dealing at arm's length with the debtor, that the transfer simply had the effect of giving the creditor a preference over the debtor's other creditors.

The first three components of a preferential transfer under section 95(1) are relatively straightforward: the debtor, while insolvent, must effectuate a transfer in favour of a creditor. ${ }^{61}$

The fourth component is concerned with whether the transfer took place within the prescribed look-back period. The general look-back period, for arm's length creditors, is three months before the date of bankruptcy. ${ }^{62}$ A lengthier 12-month look-back period applies if the transfer is made to a non-arm's length creditor. ${ }^{63}$

The fifth element of section 95(1) is also two-pronged, and depends on whether or not the creditor is dealing with the debtor at arm's length. If the creditor is not dealing with the debtor at arm's length, the trustee in bankruptcy is simply required to establish a preferential effect in favour of the creditor. ${ }^{64}$ To establish preferential effect, the bankruptcy trustee must demonstrate that the creditor improved its financial position by virtue of the transfer in comparison with the position it would have been in under a hypothetical bankruptcy liquidation. ${ }^{65}$ Under the Canadian regime, a simultaneous exchange of value is not considered to have a preferential effect. ${ }^{66}$ Thus, Canadian courts view such transactions with less temporal exactitude than American lawmakers, who specifically introduced a contemporaneous exchange defence (section 547(c)(1)) that applies when a creditor furnishes value to the debtor prior to the debtor providing reciprocal value.

If the creditor and debtor are at arm's length, the trustee in bankruptcy must establish that (1) the transfer had a preferential effect in favour of the creditor, and (2) that the debtor intended such preference. ${ }^{67}$ The Supreme Court of Canada has confirmed that it is the debtor's intent (not the concurrent intent of both debtor and creditor) that is relevant to the analysis for transfers to arm's length creditors. ${ }^{68}$

Susan M Grundy et al, The Insolvency Laws of Canada (Huntington: Juris Publishing, 2006) at 141-43. BIA, supra note 3 , s 95(1)(a).

Ibid, s 95(1)(b).

Ibid, s 95(1)(b). See Owen v Royal Bank of Canada (1970), 13 CBR (NS) 200 (Ont H Ct J).

Roderick J Wood, Bankruptcy and Insolvency Law (Toronto: Irwin Law, 2009) at 193.

Re Gauvin (1962), 5 CBR (NS) 180 (Que SC (Bkcy)). See also Re Reliable Gutter Shop on Wheels Ltd (Reliable Exteriors) (1985), 68 BCLR 67 (BCSC).

BIA, supra note 3, s 95(1)(a). See Ronald CC Cuming, "Canadian Bankruptcy Law: A Secured Creditor's Heaven” (1994) 24 Can Bus LJ 17 at 30, where the author notes that "Canadian antipreference law is still dominated by the concepts embodied in the Statute of Fraudulent Conveyances, 1571," 13 Eliz 1, c 5 [Statute of Elizabeth]. Interestingly, the Statute of Elizabeth did not contain an antipreference provision. Rather, it was concerned with avoidance of fraudulent conveyances (i.e. conveyances made by a debtor on the eve of bankruptcy in exchange for little or no value, with intent to delay, hinder or defraud creditors).

Hudson v Benallack, [1976] 2 SCR 168 at 182. 


\section{ASCERTAINING THE DEBTOR'S INTENT IN TRANSFERS TO ARM'S LENGTH CREDITORS}

Section 95(2) of the BIA dictates that the preferential effect of a transfer gives rise to a rebuttable presumption that the debtor intended to prefer the creditor. This shifts the evidential burden from the trustee in bankruptcy to the arm's length creditor. Specifically, the arm's length creditor must "adduce evidence to show that the debtor's dominant intention was not to prefer the creditor but was directed to some other purpose."69 This field of jurisprudence has developed under the common law, as opposed to the consideration of codified "presumption rebuttal" provisions contained in the BIA. ${ }^{70}$ There are four general categories of cases in which arm's length creditors have successfully rebutted the presumption of preferential intent. ${ }^{71}$

\section{a. Ordinary Course Transactions}

The presumption of preferential intent can be rebutted if the arm's length creditor demonstrates that the transfer was made in the ordinary course of business (that is, in the usual manner with no intention to prefer the arm's length creditor). ${ }^{72}$ The court is interested in confirming that the usual pattern of dealings between the parties has not been altered. However, late payments may still constitute normal course transfers if the arm's length creditor can demonstrate that it was receiving payments "reasonably promptly for each shipment and the debtor was regularly paying for each as received."73

\section{b. Transactions Necessary to Stay in Business}

An arm's length creditor may also rebut the presumption of preferential intent if it can demonstrate that the debtor's dominant intention in effectuating the transfer was to remain in business (as opposed to preferring the creditor). ${ }^{74}$ This defence reveals a fuzzy logic; an arm's length creditor may introduce evidence that reveals de facto preferential intent, but nonetheless rebut the presumption of preferential intent if it demonstrates that the debtor's preferential intent was subservient to its dominant intention of "surviving." Again, the key is recognizing that it is the debtor's dominant intent (as opposed to mere intent) in effectuating the transfer that is in question. Thus, where an arm's length creditor refuses to supply further goods or services to the debtor unless it receives payments on past-due

$69 \quad$ Wood, supra note 65 at 195.

Anthony Duggan \& Thomas GW Telfer, “Canadian Preference Law Reform” (2006) 42 Tex Int’l LJ 661 at 678 .

Wood, supra note 65 at 195.

Dunn's Wholesale Distributor Ltd (Trustee of) $v$ White Veal Meat Packers Ltd (2000), 143 Man R (2d) 289 (QB). See also St Anne-Nackawic Pulp Co (Trustee of) v Logistic Stevedoring (Atlantic) Inc, [2005] NBCA 55, 255 DLR (4th) 137 at paras 13 to 17 [St Anne-Nackawic Pulp]. Arguably, this case better falls under the category of "transactions necessary to stay in business," see below note 75. Also see Canadawide Fruit Wholesalers Inc (Trustee of) v Hapco Farms Inc, 1998 CarswellQue 1942 [Canadawide Fruit Wholesalers] where the impugned transfer was disallowed in part because the creditor could not establish that it was made in the ordinary course of business.

73 Wood, supra note 65 at 195; Re Checkout Foodmarts Ltd (1977), 24 CBR (NS) 286 (Ont H Ct J). Wood, ibid at 196. 
accounts, such creditor will be able to rebut the presumption of dominant preferential intent if the debtor's business cannot survive without such supplies. ${ }^{75}$

\section{c. Pre-existing Agreements to Transfer}

An arm's length creditor may also rebut the presumption of preferential intent where the transfer is effectuated pursuant to an agreement that was concluded prior to the look-back period while the debtor was still solvent. ${ }^{76}$ The leading decision of this variety is Re Blenkarn Planer Ltd., ${ }^{77}$ in which the debtor agreed to grant a security interest in favour of the impugned creditor, but was delayed due to a fire destroying much of its property. The execution of the security documents eventually took place within the look-back period while the debtor was insolvent. Nonetheless, because the debtor's firm commitment ${ }^{78}$ to grant the security interest was given while solvent and without intent to prefer, the presumption of preferential intent was rebutted and the transfer was therefore upheld.

The same doctrine also protects a secured creditor who obtains a general security agreement covering all present and after-acquired personal property from a solvent debtor. The debtor's subsequent financial collapse, and ultimate bankruptcy, will not detriment the secured creditor's claim to property acquired by the debtor during the preference period. ${ }^{79}$ As explained by Ronald Cuming, "[i]f the security agreement was executed at a time when the debtor was solvent, the debtor could not have intended to prefer the secured party at the time the security interest attached since the attachment was pursuant to that prior agreement and not pursuant to an intention to prefer at the time of attachment."

\section{d. Diligent Creditor Doctrine}

If a debtor makes a transfer to an arm's length creditor within the look-back period in response to the creditor's collection efforts, the court may find that the presumption of preferential intent is rebutted. ${ }^{81}$ Roderick Wood elegantly outlines the peculiarities of this method of rebutting the presumption of preferential intent as follows:

[C] ourts have sometimes focused on the conduct of the creditor. They state that, although dishonest creditors should be punished, the law does not punish creditors for diligence. This is puzzling since it is the intention

Re Kovalcik (1973), 18 CBR (NS) 69 (Ont H Ct J); Davis v Ducan Industries Ltd (1983), 45 CBR (NS) 290 (ABQB); St. Anne-Nackawic Pulp, supra note 72. See also Andrews (Trustee of) v Minister of National Revenue, [2011] MBQB 50, 75 CBR (5th) 305 at para 47, where Dewar J held that the debtor's dominant intent of survival must be objectively viable: "If that dominant intention of the debtor is simply wishful thinking, it will not displace the presumption, however honestly the debtor may hold it.” See also Canadawide Fruit Wholesalers, supra note 72, where the impugned transfer was disallowed in part because it was unreasonable for the debtor's principal to expect the debtor to stay in business on the basis of the impugned transfer.

Re Thunder Moon Investments Ltd (1993), 20 CBR (3d) 195 (BCSC).

(1958), 14 DLR (2d) 719 (BCSC) [Blenkarn Planer].

Wood, supra note 65 at 197, where the author notes that "negotiations or expressions of willingness to give security in the future are not enough.” See Penner Motor Products (1969) Ltd (Re) (1972), 18 CBR (NS) 32 (Man QB); Carpet Warehouse (Saskatoon) Ltd (Trustee of) v Evjens Carpert Ltd (1983), 25 Sask R 192 (QB).

Cuming, supra note 67.

Ibid at 33 [footnotes omitted].

Re Houston and Thornton (1973), 18 CBR (NS) 102 (Ont Sup Ct); Coopers \& Lybrand Ltd v O'Brien Electric Co (1983), 48 NBR (2d) 189 (NBQB); Krawchenko (Trustee of) $v$ Minister of National Revenue, [2005] MBQB 97, 198 Man R (2d) 120. 
of the debtor rather than the creditor that is significant. Some courts have required a higher threshold in respect of the pressure applied, and have held that the diligence of a creditor is relevant only if the creditor's actions cause an imminent business or commercial crisis. On this view, the creditor diligence ground is essentially a sub-variant of transactions that are necessary to stay in business. ${ }^{82}$

\section{SUMMARIZING THE ROLE OF INTENT UNDER SECTION 95}

In summary, intent plays no discernible role in a preferential transfer analysis involving non-arm's length creditors. However, it does play a prominent role in an analysis involving arm's length creditors. Specifically, intent is viewed as a primary ingredient in the establishment of a voidable preferential transfer. However, this alone does not materially escalate the trustee's evidentiary burden since the preferential effect of the transfer, itself a primary ingredient in the cause of action, creates a presumption of preferential intent and thereby shifts the evidentiary burden to the impugned creditor. The impugned creditor must then adduce evidence to demonstrate that the debtor's dominant intention was not to prefer the creditor. Canadian courts have developed a liberal array of defences that efficaciously rebut the presumption of preferential intent, thereby making it relatively easy for an impugned arm's length creditor to retain a transfer made by the debtor during the look-back period. Thus, debtor intent plays a meaningful role in determining the outcome of preferential transfer challenges under section 95 of the BIA.

\section{Preferential Transfer AVOIDANCE Under THE FRAUDULENT PREFERENCES ACT}

\section{SECTIONS 2 AND 3 OF THE FRAUDULENT PREFERENCES ACT}

Each Canadian province has enacted a preferential transfer avoidance statute. The provincial statutory provisions are, in many respects, similar to section 95 of the BIA, but also exhibit some important differences. The two operative provisions of Alberta's FPA are reproduced below:

2. Subject to sections 6 to 9, every gift, conveyance, assignment, transfer, delivery over or payment of goods, chattels or effects or of bills, bonds, notes or securities or of shares, dividends, premiums or bonus in any bank, company or corporation, or of any other property, real or personal, made

(a) by a person at a time when the person is in insolvent circumstances or is unable to pay the person's debts in full or knows that the person is on the eve of insolvency, and

(b) to or for a creditor with intent to give that creditor preference over the other creditors of the debtor or over any one or more of them,

is void as against the creditor or creditors injured, delayed, prejudiced or postponed. 
3. Subject to sections 6 to 9, every gift, conveyance, assignment, transfer, delivery over or payment of goods, chattels or effects or of bills, bonds, notes or securities or of shares, dividends, premiums or bonus in any bank, company or corporation, or of any other property, real or personal, made

(a) by a person at a time when the person is in insolvent circumstances or is unable to pay the person's debts in full or knows that the person is on the eve of insolvency, and

(b) to or for a creditor and having the effect of giving that creditor a preference over the other creditors of the debtor or over any one or more of them,

is, in and with respect to any action that within one year after the transaction is brought to impeach or set aside the transaction, void as against the creditor or creditors injured, delayed, prejudiced or postponed. $^{83}$

Section 2 of the FPA prescribes an "intent rule," whereas section 3 prescribes an "effects rule.” ${ }^{4}$ The intent rule does not specifically restrict the temporal timeframe in which a creditor may challenge a transfer, but the applicable time-bar prescribed by the Limitations Act continues to apply in the normal course. ${ }^{85}$ In contrast, the effects rule requires the challenging creditor to bring an action within one year of the impugned transaction, ${ }^{86}$ thereby limiting the timeframe in which the creditor can avail itself of the less onerous evidentiary burdens associated with the effects rule. Under both provisions, the debtor must be insolvent (under a "balance sheet" insolvency test), unable to pay its debts in full (that is, insolvent under a "cash flow" test), or on the eve of insolvency.

Unlike section 95 of the BIA, the FPA does not prescribe special preference avoidance rules for arm's length transferees and non-arm's length transferees. Instead, the FPA rules are "one size fits all.” Pursuant to the intent rule, a challenging creditor faces a more difficult task because, unlike section 95 of the BIA, the FPA does not create a rebuttable presumption of preferential intent. Further complicating matters for the challenging creditor is the courts' historical interpretation of provincial preferential transfer avoidance statutes as requiring proof of concurrent intent of both debtor and creditor, despite the absence of specific wording to such effect in the operative provisions. ${ }^{87}$ Moreover, Canadian courts have recognized a liberal defence doctrine pursuant to which no preferential intent will be found if it is demonstrated that the debtor made the transfer in response to pressure for payment from the creditor. ${ }^{88}$ Collectively, these three factors make it exceedingly difficult for a creditor to use section 2 of the FPA to successfully impeach a de facto preferential transfer to an arm's length creditor.

At first glance, section 3 of the FPA may appear quite appealing to a creditor interested in impeaching a transfer made by an insolvent debtor, since the effects rule is only concerned with "preferential effect." However, a closer examination of later provisions of the FPA

Supra note 4, ss 2-3.

Wood, supra note 65 at 200

RSA 2000, c L-12.

Interestingly, most provinces prescribe a sixty-day challenge period under the effects rule. See Wood, supra note 65 at 200.

Van Duzen v Van Duzen (2001), [2001] BCSC 1805, 23 RFL (5th) 401 at para 27.

Wood, supra note 65 at 202. 
dispels this notion considerably. Section 6 of the FPA, reproduced below, provides a challenged creditor with additional protection:

Nothing in sections 1 to 5 applies to

(a) a bona fide sale or payment made in the ordinary course of trade or calling to innocent purchasers or parties, or

(b) a payment of money to a creditor, or a bona fide conveyance, assignment, transfer or delivery over of any goods, securities or property, of any kind as above mentioned, that is made in consideration of a present actual bona fide sale or delivery of goods or other property or of a present actual bona fide payment in money, or by way of security for a present actual bona fide advance of money,

if the money paid or the goods or other property sold or delivered bear a fair and reasonable relative value to the consideration for it.

Section 6(a) exempts a bona fide sale or ordinary course payment from the avoidance provisions. Perhaps most significantly, section 6(b) generally insulates payments of money, the most common form of preferential transfer, to a creditor from the avoidance provisions. Section 9 of the FPA, reproduced below, also affords several additional protections to transferees that diminish the utility of the statute from a challenging creditor's perspective:

Nothing in this Act

(a) affects a payment of money to a creditor when the creditor by reason or on account of the payment has lost or been deprived of or has in good faith given up a valid security that the creditor held for the payment of the debt so paid, unless the value of the security is restored to the creditor,

(b) affects the substitution in good faith of one security for another security for the same debt so far as the debtor's estate is not lessened in value to the other creditors because of the substitution, or

(c) invalidates a security given to a creditor for the pre-existing debt when, by reason or on account of the giving of the security, an advance is made in money to the debtor by the creditor in the bona fide belief that the advance will enable the debtor to continue the debtor's trade or business and pay the debtor's debts in full. ${ }^{89}$

\section{Availability of Provincial Preference Avoidance PROVISIONS TO THE TRUSTEE IN BANKRUPTCY}

A trustee in bankruptcy may exercise the provincial avoidance powers of a creditor under the $B I A .{ }^{90}$ This power is in addition to, and not in substitution for, the trustee's avoidance 
power under section $95 .^{91}$ Thus, a trustee may pursue the avoidance of a preferential transfer under either section 95 of the BIA or under the applicable provincial preference avoidance statute. Given the limitations of the FPA (described above), a trustee in bankruptcy is unlikely to rely on its provincial avoidance powers in favour of its section 95 avoidance powers, which are generally more robust. However, a trustee may elect to challenge a transfer under its provincial avoidance powers as a measure of last resort when it is no longer able to challenge under section 95 of the BIA due to temporal lapses (for example, an arm's length creditor who receives a preferential transfer more than three months prior to the debtor's bankruptcy). ${ }^{92}$

\section{REFORM INITIATIVE OF THE UNIFORM LAW CONFERENCE OF CANADA}

In 2008, the Uniform Law Conference of Canada (the ULCC) tasked a working group, chaired by Tamara Buckwold, with reviewing the state of fraudulent conveyance and preferential transfer legislation across Canada. In August 2011, the working group released a report in which it recommended the enactment of uniform legislation in each province and territory that would enable creditors to challenge undervalued transactions, fraudulent transactions and preferential payments. ${ }^{93}$ Under the proposed legislation, the preferential payment avoidance provisions would not apply to payments made to arm's length creditors, and would eliminate the role of preferential intent in determining the outcomes of challenges to non-arm's length payments. ${ }^{94}$ The working group sought a mandate from the ULCC to draft a prototype Uniform Reviewable Transactions Act for consideration by the provinces and territories. ${ }^{95}$ The working group presented the model legislation to the ULCC in August 2012; the legislation received approval subject to implementation of some minor changes to be completed prior to 30 November 2012.

\section{Brief SumMary OF THE CANAdian PREFERENTIAL Transfer AVoidance Provisions}

Section 95 of the BIA separates arm's length creditors (the Canadian proxy for "noninsiders”) and non-arm's length creditors (the proxy for the US term "insider”) for two purposes: (1) to determine the length of the applicable look-back period; and (2) to determine

$91 \quad$ Wood, supra note 65 at 181.

92 John D Honsberger \& Vern W DaRe, Bankruptcy in Canada, 4th ed (Aurora: Canada Law Book, 2009) at 368 .

93 Civil Law Section: Commercial Law Strategy, Reform of Fraudulent Conveyances and Fraudulent Preferences Law, Part 2: Preferential Payments, Final Report of the Working Group, (Winnipeg, August 2011) online: Uniform Law Conference of Canada <http://www.ulcc.ca/en/2011-winnipegmb/588-civil-section-documents-2011/896-reform-of-fraudulent-conveyances-and-fraudulentpreferences-law-transactions-at-undervalue-and-preferential-transfers> [ULCC Report]. This report is the last of a series of working group reports that address preferential payments, transactions at undervalue, and fraudulent transactions. The previous reports are as follows: Civil Law Section: Commercial Law Strategy, Reform of Fraudulent Conveyances and Fraudulent Preferences Law (Transactions at Undervalue and Preferential Transfers) Part I: Transactions at Undervalue and Fraudulent Transactions, Final Report of the Working Group (Halifax, August 2010) online: Uniform Law Conference of Canada <http://www.ulcc.ca/en/2009-ottawa-on/192-civil-section-documents/402reform-of-fraudulent-conveyances-and-fraudulent-preferences-2009>; Reform of Fraudulent Conveyances and Fraudulent Preferences Law (Transactions at Undervalue and Preferential Transfers), Part 1: Transactions at Undervalue and Fraudulent Transactions, Supplementary Report of the Working Group, (Winnipeg, August 2011). ULCC Report, ibid at paras 14-15. Ibid at para 46 . 
whether debtor intent is relevant or irrelevant to the transfer avoidance analysis. Non-arm's length creditors are subject to a strict liability rule that voids an impugned transfer effectuated during the look-back period if it had the effect of preferring the creditor.

For transfers to arm's length creditors, preferential intent is a necessary ingredient. If the transfer had the effect of preferring the creditor, a presumption of preferential intent arises which must be rebutted by the impeached creditor. Arm's length creditors may rely on a variety of common law doctrines, several of which facilitate rebuttal of the presumption of preferential intent with relative ease (such as "transactions necessary to stay in business," and the "diligent creditor doctrine"). Thus, under Canadian law, intent represents more than a mere "shield" (that is, arguably more akin to a "sword") for protection of challenged creditors. ${ }^{96}$

Outside of bankruptcy, the FPA allows a creditor to challenge a preferential transfer made by an insolvent debtor under either an "effects rule" or an "intent rule." The effects rule requires the action to be brought within one year of the transfer, while the intent rule does not impose such limitation. The effects rule is one of strict liability, while the intent rule places a heavy evidentiary burden on the challenging creditor. The harshness of the effects rule is significantly lessened by the myriad of defences and exceptions (such as the payment of money exception) furnished under the FPA. In bankruptcy, a trustee may impeach a transfer using a creditor's FPA avoidance powers.

\section{Comparative ANalysis of AMERICAN AND CANADian Preferential Transfer Avoidance Provisions}

It is worthwhile to compare and contrast the American and Canadian preferential transfer avoidance regimes. Part IV applies the rules of both regimes to three distinct fact patterns and then evaluates the regimes using, as the primary evaluation benchmark, their adherence to the policy objective of distributive equality. ${ }^{97}$

\section{A. SCENARIOS: THE SySTEMS IN ACTION}

\section{SCENARIO 1: THE WidgetCO EXAMPLE}

Consider the scenario set forth in Part I involving Widgetco and Supplyco. Under American law, the trustee in bankruptcy cannot utilize its avoidance powers under the UFTA because Supplyco is not an insider of Widgetco. However, the trustee may rely on section 547(b) of the Bankruptcy Code. The January payment to Supplyco satisfies all the criteria of a prima facie preferential transfer under section 547(b). Unless Supplyco can establish that the January payment constituted an ordinary course payment under section 547(c)(2) of the Bankruptcy Code (which it cannot do based on the facts presented), the trustee in bankruptcy will be successful in clawing back the payment for the benefit of all unsecured creditors (including Supplyco). 
Under Canadian law, the January payment to Supplyco clearly satisfies four of the five criteria under section 95(1). The fifth element concerns the effect of the transfer and the debtor's intent. Since the payment to Supplyco had a preferential effect, section 95(2) of the $B I A$ creates a presumption that Widgetco intended to prefer Supplyco. Supplyco can rebut the presumption of preferential intent if it can establish that Widgetco's dominant intention in making the payment was to stay in business. Indeed, the facts support this conclusion. Moreover, if Supplyco could introduce evidence that it demanded payment from Widgetco, it may be able to rebut the presumption of preferential intent under the "diligent creditor" doctrine. The trustee in bankruptcy will have no better luck challenging the transfer using its provincial avoidance powers because the transaction involved the payment of money.

Simply put, the outcome of the bankruptcy trustee's challenge in Scenario 1 will depend on whether events transpired north or south of the 49th Parallel.

\section{SCENARIO 2: AFTER-ACQUIRED PROPERTY}

Consider the following scenario. On 1 January 2012, X executes an agreement granting $\mathrm{Y}$ a security interest in certain present and after-acquired property that does not include inventory or receivables. Y registers ${ }^{98}$ a financing statement properly describing its collateral. $\mathrm{X}$ and Y are unaffiliated companies operating at arm's length. On 1 December 2012, X becomes insolvent, and on 1 April 2013, makes an assignment ${ }^{99}$ in bankruptcy.

Under American law, the trustee in bankruptcy cannot challenge the transaction using its UFTA avoidance powers because $Y$ is not an insider of X. However, under section 547(b) of the Bankruptcy Code, the secured transaction between $\mathrm{X}$ and Y produces "a preferential transfer voidable by the trustee to the extent” that any of Y's unsecured debt, as of 1 January 2013, "was thereafter converted into secured debt through the automatic attachment of a security interest in the property, other than replacement property, acquired by the debtor."100 None of the defences prescribed in section 547(c) will be available to Y, and the converted security will be clawed back.

Under Canadian law, the trustee will be unable to void the conversion of unsecured debt to secured debt during the preference period. Although Y received a de facto preference, $\mathrm{Y}$ will be able to establish that X's dominant intention in executing the security agreement on 1 January 2012 was not to prefer Y over X's other creditors. ${ }^{101}$ In order to establish a voidable preferential transfer under Canadian law, the trustee in bankruptcy would need to establish that $\mathrm{X}$, an insolvent debtor, intended to prefer $\mathrm{Y}$ on the date it executed the security agreement. Unfortunately for the trustee, the facts do not bear this out. Nor will the trustee have success impeaching the transaction under the FPA, again because it cannot establish intent. $^{102}$

Or, in US parlance, "files” a financing statement.

Or, in US parlance, "files" for bankruptcy.

Cuming, supra note 67 at 34 .

Ibid at 33; Blenkarn Planer, supra note 77.

Cuming, supra note 67 at 33. 
As in Scenario 1, the geographic peculiarities of the Scenario 2 events will have a direct bearing on the outcome of the bankruptcy trustee's challenge.

\section{SCENARIO 3: CROSS-BORDER COMPLICATIONS}

Matters are complicated when a cross-border element is introduced into the fact pattern. ${ }^{103}$ Imagine the facts set out in Scenario 1, but with a slight twist. Instead of Widgetco and Supplyco both being located in the same jurisdiction, either in the US or Canada, they are now located in different jurisdictions. Widgetco is incorporated, and carries on business, in the US; Supplyco is incorporated, and carries on business, in Canada. Widgetco files for bankruptcy protection under the Bankruptcy Code. ${ }^{104}$

The trustee in bankruptcy will wish to impeach the transfer under American antipreference law because, as demonstrated above, it will be successful in avoiding the transfer to Supplyco under a section 547 analysis. ${ }^{105}$ In contrast, Supplyco will want the antipreference analysis conducted under Canadian law because it will be able to rebut the presumption of preferential intent (created by section 95(2) of the BIA) with relative ease, thereby legitimizing the impugned transfer. ${ }^{106}$ The bankruptcy court will be forced to make a choice-of-law determination; that is, whether the anti-preference analysis should be conducted under section 547 of the Bankruptcy Code or section 95 of the BIA. The choice is not obvious because neither statutory provision is expressly limited in terms of its territorial reach. ${ }^{107}$

The choice-of-law analysis requires the court to determine which jurisdiction has the closest connection to the transaction. ${ }^{108}$ This is commonly referred to as the "center of gravity" test. ${ }^{109}$ To determine which jurisdiction has the closest connection, the court will consider a variety of factors including the primary location of the debtor's business and assets, the jurisdiction in which the transfer primarily occurred, ${ }^{110}$ and the location of the creditor. ${ }^{111}$ The case law suggests that, given the American location of Widgetco and the transfer, section 547 of the Bankruptcy Code will apply in Scenario 3. ${ }^{112}$ As such, the trustee in bankruptcy will be successful in avoiding the transfer.

Westbrook, supra note 16

Pursuant to $\S 109$ of the Bankruptcy Code, supra note 3, a debtor may file for bankruptcy if it has property located in the US. Similarly, in Canada, a debtor need only have some property located in the country in order to file for bankruptcy. See Wood, supra note 65 at 551, referring to the definition of "insolvent person" under s 2 of the BIA.

Caulfield, supra note 96 at 611 .

Ibid at 612 .

In the US, courts have recognized a "presumption against extraterritoriality,” which essentially embraces the theory that Congressional legislation, absent a clear expression to the contrary, is presumed to apply within the territorial bounds of the US and not beyond. See In re Maxwell Communication Corp PCL by Homan, 93 F (3d) 1036 (2nd Cir 1996) [Maxwell]. However, as noted by Jay Westbrook, courts may find Congressional intent buried in the language of the provision or in the policy underlying the provision. See Jay Lawrence Westbrook, “Avoidance of Pre-Bankruptcy Transactions in Multinational Bankruptcy Cases” (2006-2007) 42 Tex Int'l LJ 899 at 906.

Maxwell, ibid at 1051.

In re Florsheim Group Inc, 336 BR 126 (Bkrtcy ND Ill 2005) at 130 [Florsheim].

Ibid at 129.

Wood, supra note 65 at 554.

Florsheim, supra note 109 (the court held that the US was the center of gravity in a transaction for the sale of shoes from a Taiwanese manufacturer to a US retailer. Interestingly, the court held that the transfer (i.e. the payment for the shoes) took place in the US). 
If the facts in Scenario 3 were reversed and Widgetco was located in Canada and Supplyco in the US, the choice-of-law analysis would dictate the application of section 95 of the BIA, which would resolve the matter in favour of Supplyco. ${ }^{113}$ Although the problem would get thornier if Widgetco and Supplyco were each multi-national corporations with operations in both the US and Canada, the case law suggests that the "center of gravity" test would continue to apply. ${ }^{114}$ Indeed, a seemingly infinite number of details and factors could be introduced to further complicate the cross-border scenario. ${ }^{115}$ In any event, it is clear that geographic peculiarities (some of which are subject to manipulation by the parties) will have a direct bearing on the ultimate success or failure of an anti-preference challenge involving a cross-border element.

One might observe that the substantial "standardization" of substantive anti-preference provisions in the US and Canada would render the choice-of-law analysis relatively inconsequential, and would therefore address forum-shopping concerns. ${ }^{116}$ This is not to suggest that either jurisdiction should bring its commercial laws in line with the other solely to avoid choice-of-law anomalies. Indeed, each country may have a unique set of interests that dictates the enactment of a correspondingly distinct set of rules. ${ }^{117}$ However, if, on a principled basis, it is determined that Sovereign A has superior anti-preference law that addresses the unique interests of Sovereign B (and therefore ought to be considered for adoption by Sovereign B), the benefits of standardization (including eradication of choice-oflaw anomalies) provide Sovereign B with an additional incentive to proceed with legislative reform.

Wood, supra note 65 at 554 . Wood notes that it "remains to be seen" whether Canadian courts will adopt a similar choice-of-law approach to that adopted by the Maxwell and Florsheim courts.

114 Maxwell, supra note 107 (the US court held that payments made from one multi-national corporation to several other multi-national corporations were closely connected to the United Kingdom, thereby requiring application of the UK anti-preference provisions).

115 Holt Cargo Systems Inc v ABC Containerline NV (Trustees of), [2001] 3 SCR 907 at 945. Both the Bankruptcy Code and the BIA have adopted cross-border provisions that provide for the recognition by local courts of foreign insolvency proceedings and foster cooperation among courts and parties to multijurisdictional insolvency proceedings. For example, the BIA cross-border provisions permit a trustee in a US insolvency proceeding (i.e. a "foreign representative") to bring an application before a Canadian court for an order recognizing the US insolvency proceeding. Similarly, the Bankruptcy Code crossborder provisions permit a Canadian foreign representative to apply to a US court for an order recognizing a Canadian insolvency proceeding. Theoretically, the cross-border provisions should not affect or interfere with choice of law determinations under the "center of gravity" test described above, and therefore, as a general matter, should not have a direct bearing on the resolution of any particular anti-preference challenge. However, the most interesting aspect of the cross-border provisions in both statutes, in respect of anti-preference policy, is the "hotchpot" rule embodied in section 1532 of the Bankruptcy Code and s 283 of the BIA. For example, s 283 of the BIA provides that a dividend received by a creditor in a foreign insolvency proceeding will be accounted for in the distribution of Canadian assets, and may leave such creditor unable to claim in the Canadian scheme until other creditors receive the same percentage of their claim as such creditor received in the foreign insolvency proceeding. As described by Wood, the effect of s 283 of the BIA, in the anti-preference context, is that "BIA provisions respecting preferences and transfers at an undervalue can be effectively imposed on transfers that occur outside Canada, even though the transactions could not be impugned by the application of foreign avoidance law in the foreign insolvency proceeding" (Wood, supra note 65 at 564-65). For a more detailed account of s 283 and the application of the hotchpot rule under the BIA's cross-border provisions, see Wood, supra note 65 at 564. See also UNCITRAL, supra note 18 at 359-60 for a general discussion of the hotchpot rule in bankruptcy cross-border provisions. 


\section{B. Evaluating THE Systems}

In reflecting on the stark contrast in outcome of the scenarios described above, an obvious question arises. Between American anti-preference law on one hand, and Canadian antipreference law on the other, which system is preferable? ${ }^{118}$ In each scenario, the American anti-preference provisions would allow the trustee in bankruptcy to claw back the impugned transfer; the Canadian anti-preference provisions, in contrast, would permit the challenged creditor to retain such transfer based on a demonstrated lack of preferential intent. ${ }^{119}$ Which outcomes better adhere to the distributive equality policy objective?

In Scenarios 1 and 3, ${ }^{120}$ each dollar of the impugned transfer that Supplyco is permitted to retain is one less dollar available for distribution among Widgetco's general creditors. ${ }^{121}$ There is no compelling reason, informed by either anti-preference policy objective, ${ }^{122}$ why Supplyco should retain this transfer at the expense of Widgetco's other suppliers. ${ }^{123}$ In Scenarios 1 and 3, the American anti-preference provisions (which would claw back the impugned transfer) are preferable to their Canadian counterparts (which would allow retention of the impugned transfer) because the former provisions create equality among similarly situated creditors. Simply put, in both scenarios, the Canadian outcome does violence to the distributive equality policy objective, ${ }^{124}$ while the American outcome does not.

Similarly, in Scenario 2, the policy goal of distributive equality is better achieved under the American regime, which would claw back the converted security. Again, there is no countervailing policy objective that justifies the opposite result delivered by the Canadian regime. Why should a creditor be entitled to convert unsecured claims to secured claims during the preference period at the expense of other creditors? Every dollar that accrues to the secured creditor's benefit through the conversion is a dollar unavailable for distribution among other general creditors. ${ }^{125}$ Again, the Canadian outcome does violence to the distributive equality policy objective, while the American outcome adheres to it.

Pun intended.

In Scenario 1, Canadian law permits Supplyco to retain the payment because Widgetco's dominant intention was to survive, not to prefer Supplyco. The fact that Widgetco may have had a subservient intention of preferring Supplyco is of limited relevance. In Scenario 2, Canadian law provides that $Y$ may retain the security converted during the preference period. Since attachment during the preference period occurred automatically pursuant to the terms of the security agreement (and not through some proactive step taken by $\mathrm{X}$ during the preference period), $\mathrm{Y}$ is able to retain the benefit of the security conversion.

$120 \quad$ Scenario 3 is a sub-variant of Scenario 1.

121 This general group of creditors would generally include Supplyco.

122 Supra note 19.

123 This is not to suggest that Widgetco or Supplyco did anything wrong in connection with the transfer. To the contrary, Widgetco made the payment to Supplyco as part of a good faith attempt to salvage its struggling business. Even if one or both of the parties did exhibit preferential intent in connection with the impugned transfer, such fact is irrelevant. Anti-preference analysis should not concern itself with moral condemnation; at its best, anti-preference analysis is morally ambivalent.

124 UNCITRAL, supra note 18 at 153. Notably, UNCITRAL does not recommend inclusion of an element of intent in anti-preference provisions. Consider, also, UNCITRAL's following statement, at 141, questioning the appropriateness of an intent element in an anti-preference regime: "These potential difficulties underscore the desirability of an insolvency law adopting clear and predictable avoidance criteria and defences that will enable all parties to assess potential risks and avoid disputes, for example objective criteria focusing on the effect or result of transactions rather than on the intent of the parties." In this example, but for the security conversion, $\mathrm{Y}$ would be a general creditor with respect to the converted amount. 
The American regime is preferable to the Canadian one because, as demonstrated, it better adheres to the guiding policy objective of distributive equality among similarly situated creditors. As a general matter, the American regime better adheres to this policy objective because it is premised on the more accurate and intellectually appealing notion that creditors are harmed by actions, not intentions. To be sure, under the American regime, intent can play a role in affording an impugned creditor a defence in narrowly defined circumstances. ${ }^{126}$ However, the role of intent under the American regime is notably less pronounced when compared to and contrasted with its role under the Canadian regime. Indeed, intent is a chief ingredient in an arm's length transfer avoidance challenge in Canada. Cuming offers a powerful critique of the Canadian approach, as follows:

The traditional approach embodied in s. 95 of the BIA provides a test: the intention of the debtor. Only if the insolvent debtor intends to prefer a creditor is the preferential payment or transaction objectionable. However, this approach is not only difficult to apply, but, to a great extent, it misses the point. The point is that the transfer, if left intact, frustrates implementation of the policy of bankruptcy legislation, equitable treatment of all creditors. The fact that the debtor intended or did not intend this result should not be relevant. The actual or presumed intentions of the debtor when making a preferential transfer are not important. What is important is the effect that such a transfer has on the position of creditors with claims in bankruptcy. What matters to them is that a central policy of bankruptcy law is not frustrated by a preferential payment or transfer which, by definition, results in material loss to them. ${ }^{127}$

Cuming's contention that Canadian lawmakers have "missed the point" is persuasive. Evidence of the confused state of Canadian anti-preference law is revealed in the fuzzy, and sometimes downright puzzling, logic employed by Canadian courts charged with resolving anti-preference litigation. Confusion is unsurprising, and perhaps inevitable, when one recognizes that the element of intent in a preferential transfer analysis is wholly incompatible with the anti-preference regime's chief policy goal: ensuring equality of distribution among similarly situated creditors. ${ }^{128}$ Indeed, giving intent significant weight in an anti-preference analysis is akin to performing Euclidean geometry on a Non-Euclidean plane.

\section{CONCLUSION}

In both the US and Canada, bankruptcy preferential transfer avoidance provisions are aimed at creating equality of distribution among similarly situated creditors. ${ }^{129}$ In 1978 , US Congress, recognizing the disconnect between policy and law (that is, an anti-preference rule that inquired into the parties' intent), opted to amend the law; an eminently sensible decision. Indeed, the preferential transfer avoidance rules set out in the Bankruptcy Code are largely consonant with the notion that a debtor's malicious motives do not harm creditors. Creditors are harmed by actions, not intentions. ${ }^{130}$

Notably, even these defences have drawn criticism from anti-preference "hardliners" who, for example, view the "ordinary course payments" defence as a relatively simple means of thwarting the very policies underlying modern preferential transfer avoidance provisions. See Tabb, supra note 39. Ronald CC Cuming, "Transactions at Undervalue and Preferences Under the Bankruptcy and Insolvency Act: Rethinking Outdated Approaches” (2002) 37 Can Bus LJ 5 at 23. Ponoroff, supra note 15 at 1470-77 where the author discusses policy considerations, chief among them being the policy objective of distributive equality.

129 See Westbrook, supra note 16. 
North of the border, progress is currently underway to implement a substantially revised anti-preference regime at the provincial level under the prototype Uniform Reviewable Transactions Act, ${ }^{131}$ which would more or less bring Canadian provincial law in line with US state law. ${ }^{132}$ Why, then, is serious progress not afoot at the federal level to bring section 95 of the BIA more in line with section 547 of the Bankruptcy Code? There is no good explanation for this. In order to unify policy and law, Parliament should abandon the notion that intent is a necessary element of a voidable preferential transfer. ${ }^{133}$ Until suitable reform is introduced, Canada will remain stuck with 19th century anti-preference law.

Uniform Law Conference of Canada, Uniform Reviewable Transactions Act (Whitehorse, August 2012), online: Uniform Law Conference of Canada <http://www.ulcc.ca/en/uniform-acts-en-gb-1/615reviewable-transactions-act/1390-uniform-reviewable-transaction-act2012>.

This point should not be overstated. Harmonization of Canadian provincial law and US state law was not a primary motivating factor in the development of anti-preference reform under the Uniform Reviewable Transactions Act, ibid. Nor can it be said that the ULCC working group's focus was the elimination of intent from Canadian anti-preference analysis per se. Rather, the working group was motivated by a desire (a welcome one, in my view) to create greater consistency between the provincial and federal anti-preference regimes. That said, the model statute implicitly rejects the debtor intention test by omitting arm's length grounds for relief. Moreover, in developing its legislative framework, the ULCC working group openly criticizes the intent element in the BIA's arm's length test. See ULCC Report, supra note 93 at para 14: "The creation of a provincial cause of action designed to maintain the desired consistency of approach with the BIA would require the imposition of a 3 month limitation period and retention of the intention to prefer test that is a primary factor in the dysfunctional state of existing law. Such an approach would serve only to create uncertainty without offering creditors any meaningful protection against disproportionate voluntary payments.” See also Tamara M Buckwold, "Reforming the Law of Fraudulent Conveyances and Fraudulent Preferences" (2012) 52 Can Bus LJ 333 at 358.

133 As noted above, bringing section 95 of the BIA in line with $\S 547$ of the Bankruptcy Code would have the happy consequence of substantially eliminating choice-of-law anomalies. 